\title{
EXPERIMENTAL STUDY OF THE ACTION OF COX-2 SELECTIVE NONSTEROIDAL ANTI-INFLAMMATORY DRUGS AND TRADITIONAL ANTI-INFLAMMATORY DRUGS IN BONE REGENERATION
}

\author{
Bruno C. Tiseo, Guilherme N. Namur, Emygdio J. L. de Paula, Rames Mattar
}

Junior, and Claudia R. G. C. M. de Oliveira

Tiseo BC, Namur GN, de Paula EJL, Mattar Junior R, de Oliveira CRGCM. Experimental study of the action of COX-2 selective nonsteroidal anti-inflammatory drugs and traditional anti-inflammatory drugs in bone regeneration. Clinics. 2006;61(3):223-30.

OBJECTIVE: The aim of this study is to compare the effects of traditional nonsteroidal anti-inflammatory drugs with nonsteroidal anti-inflammatory drugs that are selective cyclooxygenase-2 (COX-2) inhibitors in the process of bone regeneration in a rat model.

MATERIALS AND METHODS: Forty-four Wistar strain rats were subjected to osteotomy of the right femur and randomly divided into 3 groups according to the drug to be given (diclofenac, rofecoxib, or placebo). Each group was divided into 2 subgroups according to the time to euthanasia after the surgery. The animals of Subgroup 1 were submitted to euthanasia 2 weeks after surgery, and those of Subgroup 2, underwent euthanasia 4 weeks after surgery. Radiographic examinations and bone callus histomorphometry were analyzed.

RESULTS: No intergroup statistical difference was found in the bone callus area or in bone formation area 2 and 4 weeks after surgery. Intra-group analysis concerning the bone neoformation area inside the callus showed a significant difference within the diclofenac group, which presented less tissue.

CONCLUSIONS: Fracture consolidation in Wistar rats occurs within less than 2 weeks, and the use of nonsteroidal antiinflammatory drugs does not significantly influence this process.

KEYWORDS: Anti-inflammatory agents, nonsteroidal. Bone regeneration. Fracture consolidation. Rats, Wistar. Osteotomy.

\section{INTRODUCTION}

Prostaglandins (PGs) are local, autacoid hormones formed by the oxygenation of arachidonic acid (AA) from cell membranes from which it is removed by phospholipase A2 (PLA2). Prostaglandins are produced by cyclooxygenase (COX), an enzyme also known as prostaglandin $\mathrm{H} 2$ synthase (PGHS). Cyclooxygenase is responsible for 2 reactions involving AA: the first reaction converts AA into the highly

Department of Orthopedics and Traumatology, São Paulo University Medical School - São Paulo/SP, Brazil.

Email: rames@usp.br

Received for publication on October 27, 2005.

Accepted for publication on March 17, 2006. unstable Prostaglandin G2, and the second converts Prostaglandin G2 into Prostaglandin H2. Each tissue metabolizes Prostaglandin $\mathrm{H} 2$ in a different manner according to the enzymes in it, generating different active metabolites of this substance. Although they are better known for their effects as mediators of inflammatory processes, Prostaglandins play an important role in other physiological processes, such as protection of the gastric mucosa, activation of the platelet system, and regulation of renal blood flow, in addition to acting as neurotransmitters. ${ }^{1-10}$

Until recently it was thought that the AA concentration, and therefore the action of phospholipase A2, was the limiting factor for the production of PGs. ${ }^{11}$ It is now known that the limiting stage is the one mediated by COX. 
At first it was thought that only 1 type of COX existed. It was only in the beginning of the 1990s that studies in cells of rat ovaries ${ }^{12}$ produced the first evidence for a second isoform of COX. At the same time, the conclusion was reached that the already known isoform, now called cyclooxygenase-1 (COX-1), is constitutive, meaning that it can be found regularly in tissues, while the other isoform, called cyclooxygenase-2 (COX-2), is expressed only through signaling. ${ }^{13}$ Finally in 1992the COX-2 gene was cloned. ${ }^{14}$

The fact that COX-1 is expressed constitutively while COX-2 is expressed in events such as inflammation suggests a more physiologic role for the first enzyme, while COX-2 would be more important in the production of PGs in pathological processes. Because of this, the benefit of using drugs that selectively inhibit COX-2, thus preventing frequent gastric disorders (such as ulcers), and changes in the coagulation mechanism, nephrotoxicity-all adverse reactions that prevent prolonged use of traditional nonsteroidal anti-inflammatory drugs (NSAIDs), which inhibit the activity of both COX-1 and COX-2 - can be clearly seen. ${ }^{15-19}$

However, it is known that COX-2 is not involved only in inflammatory processes. It is also important in a series of physiological processes such as child birth labor, when it acts by promoting mechanisms that facilitate uterine contractions. ${ }^{9,15}$

Prostaglandins play an important role in bone metabolism. Recent studies have shown that in COX-2 knockout mice compared to COX-1 knockout mice, there is also a decrease in bone resorption in response to parathyroid hormone (PTH). ${ }^{20}$ In cultures of human cells, it has been shown that PTH is responsible for an increase in COX-2 expression and, consequently, of PGs in bone tissue. ${ }^{10}$

At lower concentrations, ${ }^{10}$ PGs seem to have an effect on the formation of bone tissue. ${ }^{21,22}$ Studies have shown that the production of lamellar bone induced by mechanical stress is mediated by COX-2.23,24

It is increasingly believed that PGs are important in bone repair, since tissue levels of PGs increase between Day 3 and Day 14 after fracture in rabbit tibias..$^{25}$

Fracture consolidation is a complex process involving intramembranous bone formation and direct differentiation of mesenchymal cells into osteoblasts, as well as endochondral ossification, when the bone matrix is deposited onto cartilage.

A study that used COX-2 knockout mice showed that both types of ossification are impaired by the absence of this enzyme. The most striking point in this study was the persistence of mesenchymal cells in the site of the fracture, ${ }^{26}$ pointing to an important role of PGs in the differentiation of these cells into osteoblasts. The study also pointed to a possible role of PGs in the recruiting of mesenchymal cells as well as in remodeling of the bone scar or callus.

Based on these experimental findings and because of the use of selective COX-2 inhibitors in medical practice, it is important to study their effects of on the process of bone regeneration.

\section{OBJECTIVE}

The objective of this study is to compare the effects of using traditional nonsteroidal anti-inflammatory drugs (NSAIDs) and NSAIDs that are selective COX-2 inhibitors in the process of bone regeneration in a rat model. We analyzed radiographic findings and histomorphometric data of the callus related with the time to regeneration of the fracture and bone neoformation area inside the callus.

\section{MATERIAL AND METHODS}

Forty-four Wistar strain rats weighing $341 \pm 31$ grams (mean $\pm \mathrm{SD}$ ) were used for this study. The rats were kept in controlled conditions of temperature and lighting and with no restriction on food or water. All rats were submitted to an osteotomy of the right femur with a mechanical saw and osteotome. The rats were then randomly divided into 3 groups $(1,2$, and 3$)$ according to the drug to be given. Each group was divided into 2 subgroups according to the time to euthanasia after the surgery: Subgroup 12 weeks (14 days) after the surgery and Subgroup 24 weeks (28 days) after the surgery as follows: placebo (P), P.1 Group 2 weeks and P.2 Group 4 weeks; diclofenac (D) D.1 Group 2 weeks and D.2 Group 4 weeks; and rofecoxib (R), R.1 Group 2 weeks and R.2 Group 4 weeks.

Thirteen animals were not included in the study: 9 due to infection and 4 due to bone fixation failure (Kirschner wire migration). All groups included 5 rats each, except for the R.1 Group, which included 6 animals.

The rats in the $\mathrm{P}$ groups received orally $1.25 \mathrm{~mL} / \mathrm{kg}$ of a solution made of 2 parts of condensed milk and 1 part of water, once daily, at the same time every day. The animals in the D groups received a similar solution of $3 \mathrm{mg} /$ $\mathrm{kg}$ diclofenac sodium (a nonselective COX inhibitor), while the rats in the $\mathrm{R}$ groups received rofecoxib (a selective COX-2 inhibitor) at a dose equivalent to $1 \mathrm{mg} / \mathrm{kg}$. These dosages were selected based in experimental and clinical studies. ${ }^{9,10,15-17}$ The animals were weighed once a week for drug dose adjustment.

Fracture. All animals were anesthetized using thiopental and ketalar. The right hind limb of each rat was prepared for surgical procedure. After assembling the surgi- 
cal table in a laminar air flow environment, the animal was positioned, and a $2 \%$ iodine solution was first used externally as an antiseptic.

A $2.5-\mathrm{cm}$ incision was made along the femoral diaphysis. The subcutaneous and muscular planes were incised until the bone plane was reached.

The femur was exposed, a small mechanical saw was used to weaken the cortical bone layer (Figure 1), and an osteotome was used to finish the osteotomy (Figure 2).

Intramedullary bone fixation was performed using a 1.25$\mathrm{mm}$ diameter Kirschner wire and an electric drill (Figures 3 and 4). The wound was closed using 4-0 nylon sutures.

The animals of Subgroups 1 (P.1, D.1, and R.1) were subjected to radiologic examination 15 days after osteotomy and 30 minutes prior to euthanasia. The animals of Subgroups 2 (P.2, D.2, and R.2) underwent a radiologic examination 2 and 4 weeks after osteotomy; the second exam was performed 30 minutes prior to euthanasia. Radiographs were taken to enable the analysis of bone union in the fracture area. Each radiograph was evaluated independently by 2 orthopedists blinded to the procedure.



Figure 1 - Femur osteotomy with manual saw

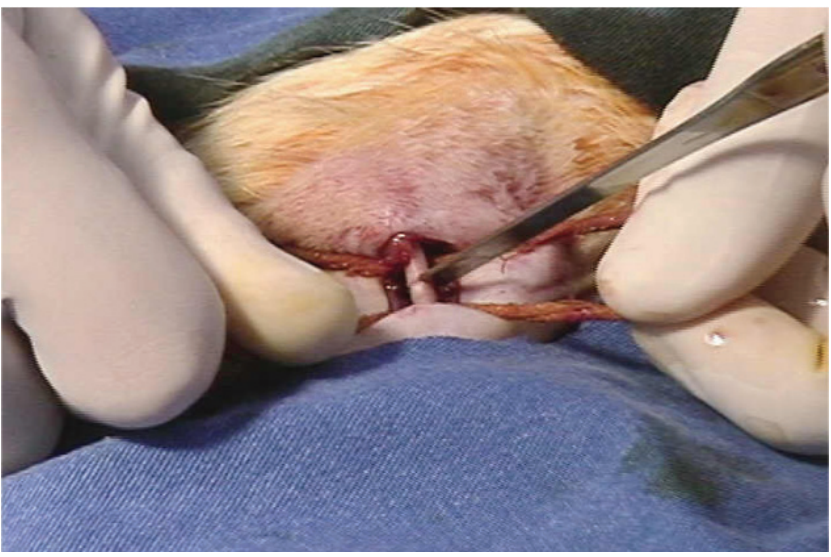

Figure 2 - End of the femur osteotomy with manual saw
After euthanasia, the femur was extracted without removing the Kirschner wire, placed in a glass container with approximately $100 \mathrm{~mL}$ of a $10 \%$ formol solution, and sent for histomorphometric analysis of the bone callus. A single pathologist experienced in bone tissue analysis performed the anatomical and pathological assessment. This histomorphometric assessment was blinded and measured the bone callus area and the neoformation areas inside the callus in square micrometers (Carl Zeiss AxioVision software).

The statistical analysis of the callus area and the bone neoformation area inside the callus among the 2-week subgroups (P.1 vs D.1 vs R.1) and among the 4-week subgroups (P.2 vs D.2 vs R.2) was performed using the nonparametric KruskallWallis and Dunn tests. For intragroup analysis (P.1 vs P.2; D.1 vs D.2; R.1; R.2), the Mann-Whitney test was used. We considered $P<0.05$ to indicate a statistically significant difference. The total area, by individual animal, of the bone callus area and of the bone neoformation area inside the callus for each group is listed in Tables 5,6,7, and 8.



Figure 3 - Intramedullary nail fixation of the femur

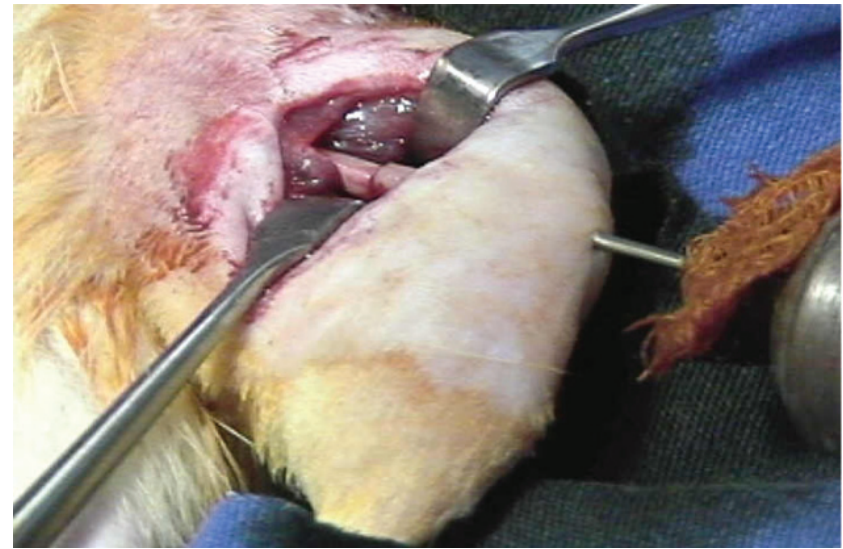

Figure 4 - Internal fixation of the femur with intramedullary nail 


\section{RESULTS}

Radiological examination. The orthopedists had difficulty in analyzing the X-rays. When asked to evaluate consolidation, quality of consolidation, and mechanical strength of the callus, they could only define whether consolidation was present or not. Both considered that all animals presented radiographic signs of consolidation in the examinations performed at 2 and 4 weeks after osteotomy.

Histomorphometric examination. In the Subgroup 1 (euthanasia at 2 weeks after osteotomy) no statistical difference was found concerning the bone callus area (Figure 5) or the bone neoformation area inside the callus $P=0.838$ and $P=0.366$, which was confirmed by the Dunn test (Tables 1 and 3, Figure 6). In the Subgroup 2 (euthanasia at 4 weeks) there was no statistical difference in the bone callus area or in the bone neoformation area inside the callus $(P=0.9254$ and $P=0.858$, respectively (Tables 1 and 3 ).

No significant intragroup difference was found regarding the amount of callus formation (Table 2). The intra-

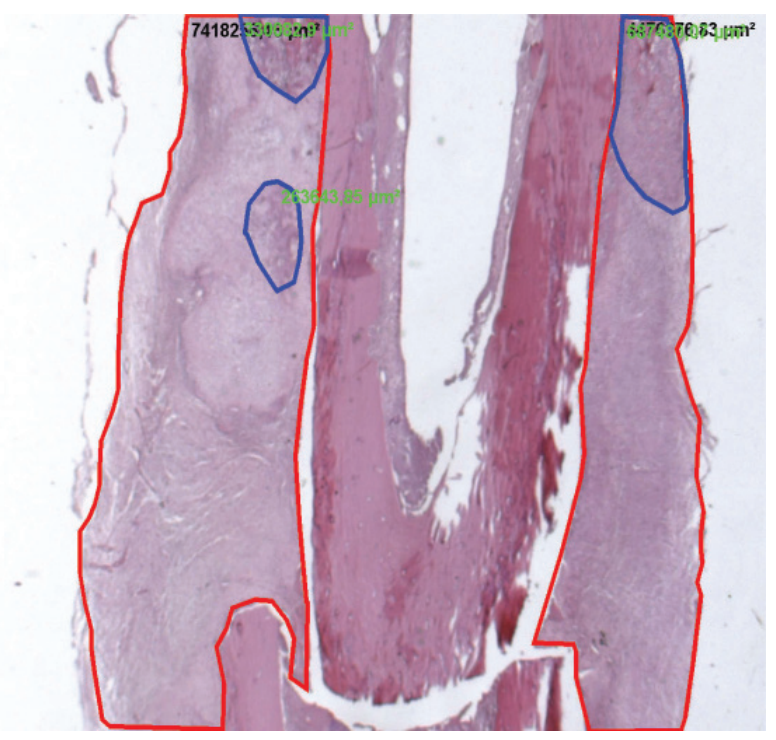

Figure 5 - Bone callus (red)

Table 1 - Intergroup comparison of bone callus area among the groups withat 4 and 2 weeks after osteotomy

\begin{tabular}{lcc}
\hline $\begin{array}{l}\text { placebo vs rofecoxib } \\
\text { vs diclofenac }\end{array}$ & \multicolumn{2}{c}{$\begin{array}{c}\text { Bone Callus Area Data } \\
\text { (Kruskall-Wallis and Dunn's Test) } \\
\text { (4 weeks) }\end{array}$} \\
\hline global $\mathrm{p}=$ & 0.9254 & 0.838 \\
global & $P=0.9254$ & $P=0.838$ \\
placebo vs rofecoxib & $\mathrm{p}>0.05$ & $\mathrm{P}>0.05$ \\
placebo vs rofecoxib & $P>0.05$ & $P>0.05$ \\
placebo vs diclofenac & $\mathrm{p}>0.05$ & $\mathrm{P}>0.05$ \\
placebo vs diclofenac & $P>0.05$ & $P>0.05$ \\
rofecoxib vs diclofenac & $\mathrm{p}>0.05$ & $\mathrm{P}>0.05$ \\
rofecoxib vs diclofenac & $P>0.05$ & $P>0.05$ \\
\hline
\end{tabular}

Table 2 - Intragroup comparison of bone callus area related to the time of sacrifice ( 2 vs 4 weeks after osteotomy)

\begin{tabular}{lcc}
\hline 2 weeks vs 4 weeks & \multicolumn{2}{c}{$\begin{array}{c}\text { Bone Callus Area Data } \\
\text { (Mann-Whitney U Test) } \\
\text { two-tailed }\end{array}$} \\
$P(2$-tailed $)$ & $\begin{array}{c}\text { One-tailed } \\
P(1 \text {-tailed })\end{array}$ \\
\hline Placebo $(\mathrm{n}=5)$ & 1.000 & 0.5 \\
Rofecoxib $(\mathrm{n}=5)$ & 0.7922 & 0.3961 \\
Diclofenac $(\mathrm{n}=5)$ & 0.6905 & 0.34525 \\
\hline
\end{tabular}

Table 3 - Intergroup comparison of bone neoformation area among the groups with at 4 and 2 weeks after osteotomy

\begin{tabular}{lcc}
\hline $\begin{array}{l}\text { placebo vs rofecoxib } \\
\text { vs diclofenac }\end{array}$ & \multicolumn{2}{c}{$\begin{array}{c}\text { Bone Neoformation Area Data } \\
\text { (Kruskall-Wallis and Dunn's Test) } \\
\text { (4 weeks) }\end{array}$} \\
\hline global p $=$ & 0.858 & 0.366 \\
global & $P=0.858$ & $P=0.366$ \\
placebo vs rofecoxib & $P>0.05$ & $P>0.05$ \\
placebo vs diclofenac & $P>0.05$ & $P>0.05$ \\
rofecoxib vs diclofenac & $P>0.05$ & $P>0.05$ \\
\hline
\end{tabular}

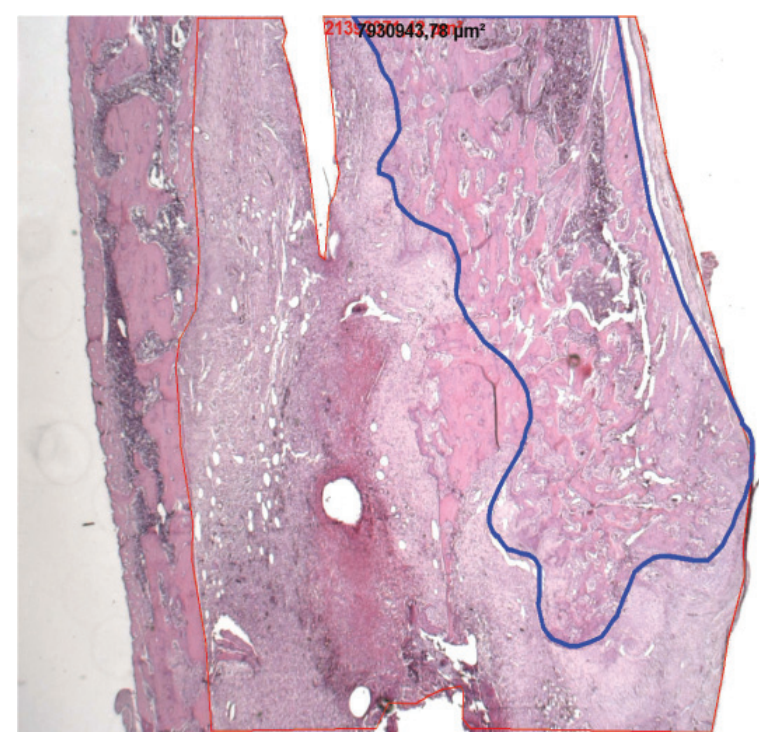

Figure 6 - Bone neoformation (blue)

group analysis of the amount of bone neoformation area inside the callus showed a significant difference within the diclofenac group only (Table 4), which had less organized bone tissue.

\section{DISCUSSION}

The radiographic examination proved to be very difficult to analyze, possibly because no comparison parameter was adopted. Since the orthopedists felt comfortable only to define presence of consolidation or absence of union of fragments, the radiograph examinations were useful for 
Table 4 - Intragroup comparison of bone neoformation area related to the time of sacrifice ( 2 vs 4 weeks after osteotomy)

\begin{tabular}{|c|c|c|}
\hline \multirow[t]{2}{*}{2 weeks vs 4 weeks } & \multicolumn{2}{|c|}{$\begin{array}{l}\text { Bone Neoformation Area Data } \\
\text { (Mann-Whitney U Test) }\end{array}$} \\
\hline & $\begin{array}{l}\text { two-tailed } \\
P(2 \text {-tailed })\end{array}$ & $\begin{array}{l}\text { One-tailed } \\
P(1 \text {-tailed })\end{array}$ \\
\hline Placebo & 0.8413 & 0.42065 \\
\hline Rofecoxib & 0.9307 & 0.46535 \\
\hline Diclofenac & 0.0952 & 0.0476 \\
\hline
\end{tabular}

Table 5 - Absolute ValuesTotal area $\left(\mu \mathrm{m}^{2}\right)$ of bone callus, by animal, area of the groups awith 4 weeks after osteotomy

\begin{tabular}{lll}
\hline $\begin{array}{l}\text { placebo 4 weeks } \\
\left(\mu \mathrm{m}^{2}\right)\end{array}$ & $\begin{array}{l}\text { rofecoxib 4 weeks } \\
\left(\mu \mathrm{m}^{2}\right)\end{array}$ & $\begin{array}{l}\text { diclofenac 4 weeks } \\
\left(\mu \mathrm{m}^{2}\right)\end{array}$ \\
\hline 6641938.57 & 10567408.86 & 38890450.63 \\
20682657.56 & 19344045.59 & 7227083.11 \\
14712615.58 & 27383555.64 & 137919396.1 \\
19421364.88 & 8211871.61 & 16307445 \\
14792818.05 & 17969138.59 & 9890636.63 \\
\hline
\end{tabular}

Table 6 - Total area $\left(\mu \mathrm{m}^{2}\right)$ Absolute Values of bone callus, by animal, area of the groups at 2 weeks after osteotomy with 2 weeks

\begin{tabular}{lll}
\hline $\begin{array}{l}\text { placebo 2 weeks } \\
\left(\mu \mathrm{m}^{2}\right)\end{array}$ & $\begin{array}{l}\text { rofecoxib 2 weeks } \\
\left(\mu \mathrm{m}^{2}\right)\end{array}$ & $\begin{array}{l}\text { Diclofenacdiclofenac } \\
2 \text { weeks }\left(\mu \mathrm{m}^{2}\right)\end{array}$ \\
\hline 13233300.56 & 7197071.96 & 9320039.32 \\
2446102.14 & 25604527.57 & 830794811.6 \\
851674992.8 & 8652712.83 & 10476857.27 \\
23812705.93 & 24555917.21 & 22604846.42 \\
11895233.29 & 14904464.09 & 51861063.88 \\
& 14013271.87 & \\
\hline
\end{tabular}

Table 7 - Total area $\left(\mu \mathrm{m}^{2}\right)$ ofAbsolute Values of bone neoformation, by animal, area of the groups with 4 weeks after osteotomy

\begin{tabular}{lll}
\hline $\begin{array}{l}\text { placebo 4 weeks } \\
\left(\mu \mathrm{m}^{2}\right)\end{array}$ & $\begin{array}{l}\text { rofecoxib 4 weeks } \\
\left(\mu \mathrm{m}^{2}\right)\end{array}$ & $\begin{array}{l}\text { diclofenac 4 weeks } \\
\left(\mu \mathrm{m}^{2}\right)\end{array}$ \\
\hline 2282761.19 & 4857981.71 & 12273142.74 \\
9033146.46 & 7387806.89 & 1519290.04 \\
4730112.13 & 8147412.04 & 10951987.46 \\
5769356.47 & 1668854.29 & 6712868 \\
6447815.92 & 9888789.98 & 3212695.29 \\
\hline
\end{tabular}

documentation purposes only. The relative stabilization obtained with the intramedullary fixation with no immobilization should have resulted in a large amount of callus, but at the end of the fourth week after osteotomy, we observed bone consolidation with no hypertrophic callus (Figure 7). Probably, a large bone callus would be seen later in this experimental model. ${ }^{21,24}$
Table 8 - Total area $\left(\mu \mathrm{m}^{2}\right)$ ofAbsolute Values of bone neoformation, by animal, area of the groups with at 2 weeks after osteotomy

\begin{tabular}{lll}
\hline $\begin{array}{l}\text { pPlaceboo 2 weeks } \\
\left(\mu \mathrm{m}^{2}\right)\end{array}$ & $\begin{array}{l}\text { rofecoxib 2 weeks } \\
\left(\mu \mathrm{m}^{2}\right)\end{array}$ & $\begin{array}{l}\text { diclofenac 2 weeks } \\
\left(\mu \mathrm{m}^{2}\right)\end{array}$ \\
\hline 7319587.63 & 3866949.2 & 3627909.45 \\
2030648.85 & 7633471.25 & 12852508.24 \\
26380765.76 & 4268346.8 & 118609787.6 \\
23812705.93 & 4435367.74 & 11641659.58 \\
1281206.82 & 8305930.49 & 21485173.75 \\
& 8396761.08 & \\
\hline
\end{tabular}

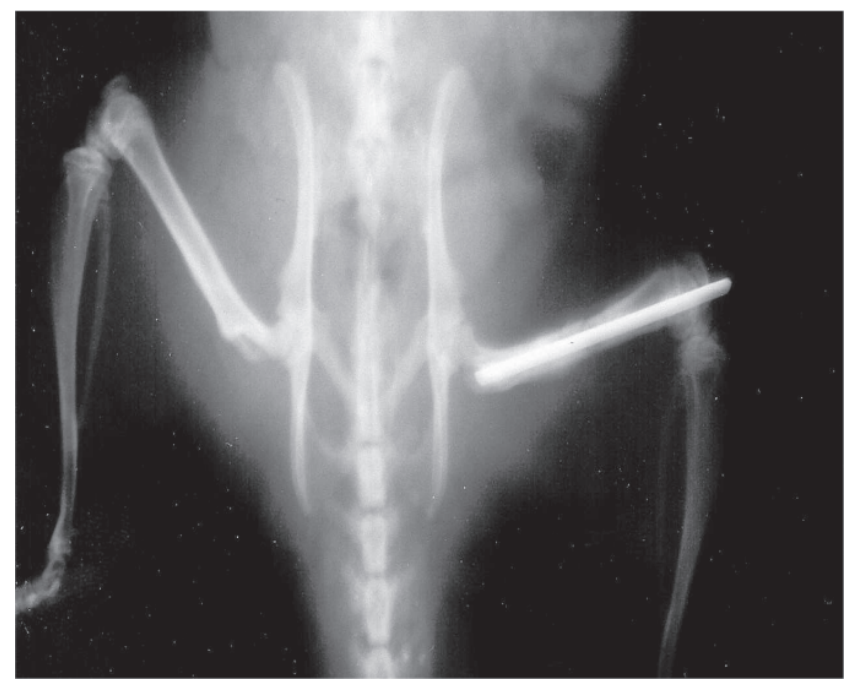

Figure 7 - Radiographic image of femur consolidation

Regarding the callus area, the histomorphometric analysis showed no differences between subgroups (P.1 vs D.1 vs R. 1 and P. 2 vs D.2 vs R.2) at either 2 weeks or 4 weeks after osteotomy. This led us to believe that the administration of selective or nonselective non steroidal anti-inflammatory agents does not interfere with bone regeneration measured as the amount of callus formation in Wistar rats. Despite the findings of other clinical and experimental studies, ${ }^{21-26}$ this model demonstrated that the administration of usually recommended doses of selective or nonselective non steroidal anti-inflammatory agents does not interfere in the ossification after bone osteotomy in the Wistar rat.

Analyzing the amount of callus formation, we did not find intragroup differences in comparing subgroups 1 and 2 (euthanasia 2 weeks and 4 weeks after osteotomy). In this model bone regeneration after bone osteotomy occurs in 2 weeks.

Concerning the comparison between the intragroup bone neoformation areas (organized bone tissue inside the bone callus), we found a significant difference within the diclofenac (D) group, since the average area of the 4-week group (subgroup 2) was smaller than that of the 2-week group (subgroup 1). It is possible that simultaneous inhibition of 
COX-1 and COX-2 may explain this phenomenon, but further research should be undertaken to explain this finding.

\section{CONCLUSIONS}

Bone consolidation in Wistar rats occurs by 2 weeks after osteotomy, and the use of selective or nonselective nonsteroidal anti-inflammatory drugs does not interfere in the amount of callus formation between 2 and 4 weeks after the osteotomy. The inhibition of COX-1 and COX-2 may restrain the production of well-organized bone neoformation areas inside the callus.
Tiseo BC, Namur GN, de Paula EJL, Mattar Junior R, de Oliveira CRGCM. Estudo experimental da ação dos antiinflamatórios não hormonais inibidores seletivos da ciclooxigenase 2 (COX-2) e anti-inflamatórios tradicionais na regeneração óssea. Clinics. 2006;61(3):223-30.

OBJETIVO: Comparar os efeitos do uso de antiinflamatórios não-esteróides tradicionais (AINES) e AINES que são inibidores seletivos da ciclooxigenase-2 (COX-2), no processo de regeneração óssea em ratos.
MATERIAL E MÉTODO: Quarenta e quatro ratos da linhagem Wistar submetidos a osteotomia do femur direito e divididos em três grupos, conforme o medicamento que receberam (diclofenaco, rofecoxib e placebo). Cada grupo foi dividido em dois subgrupos, conforme o tempo até o sacrifício, após a cirurgia. Os animais do subgrupo 1 foram sacrificados duas semanas após a cirurgia e os do subgrupo 2, quatro semanas após a cirurgia. Foram analisados exames radiográficos e a histomorfometria do calo ósseo.

RESULTADOS: Não foram encontradas diferenças esta- 
tísticas na área do calo ósseo 2 e 4 semanas após a cirurgia. No que se refere à área de neoformação óssea dentro do calo, observou-se diferença estatisticamente significante apenas dentro do grupo do diclofenaco, que apresentou menos tecido.

CONCLUSÕES: A consolidação da fratura em ratos Wistar ocorre dentro de 2 semanas e o uso de antiinflamatórios nãoesteróides não influi de forma significante neste processo.

UNITERMOS: Antiinflamatórios não esteróides. Regeneração óssea. Consolidação da fratura. Ratos Wistar. Osteotomia.

\section{REFERENCES}

1. ACR Clinical Guideline. Committee. Guidelines for the management of rheumatoid arthritis. Arthritis Rheum. 1996;39:713-22.

2. Vabne JR Tah. Inhibition of prostaglandin synthesis as a mechanism of action of aspirin-like drugs. Nat New Biol. 1971;231:232-5.

3. Smith JB, Willis AL. Aspirin selectivity inhibits prostaglandin production in human platelets. Nat New Biol. 1971;231:235-7.

4. Sirois J, Simmons DL, Richards J. Hormonal regulation of messenger ribonucleic acid encoding a novel isoform of prostaglandin endoperoxide $\mathrm{H}$ synthase in rat pre-ovulatory follicles. Induction in vivo and in vitro. J Biol Chem. 1992;267:11586-92.

5. Kujubu DA, Fletcher BS, Vamum BC, Lim RW, Herschman HR. TIS10, a phorbol ester tumor promoter-inducible mRNA from Swiss 3T3 cells, encodes a novel prostaglandin synthase/cyclooxygenase homologue. J Biol Chem. 1991;266:12866-72.

6. Xie WL, Chipman JG, Robertson DL, Erikson RL, Simmons DL. Expression of a mitogen-responsive gene encoding prostaglandin synthase is regulated by mRNA splicing. Proc Natl Acad Sci USA. 1991;88:2692-6.

7. Jones DA, Carlton DP, McIntyre TM, Zimmerman GA, Prescott SM. Molecular cloning of human prostaglandin endoperoxide synthase type II and demonstration of expression in response to cytokines. J Biol Chem. 1993;268:9049-54.

8. Luong C, Miller A, Bamett J, Chow J, Ramesha C, Browner MF. Flexibility of the NSAID binding site in the structure of human cyclooxygenase-2. Nat Struct Biol. 1996;11:927-33.

9. Kurumbail RG, Stevens AM, Glierse JK, McDonald JJ, Stegeman RA, Pak JY, et al. Structural basis for selective inhibition of cyclooxygenase2 by anti-inflammatory agents. Nature. 1996;384:644-8.

10. Maciel FMB. Expressão da ciclooxigenase-2 induzida pelo hormônio paratireóide em osteoblastos humanos em cultura [Thesis]. São Paulo: Faculdade de Medicina, Universidade de São Paulo; 1997.

11. Herschrnan HR. Prostaglandin synthase 2. Biochim Biophys Acta 1996;1299:125-40.

12. Smith WL, Marnett LJ. Prostaglandin endoperoxide synthase: structure and catalysis. Bioch Biophys Acta 1991;1083:1-17.

13. Masferrer JL, Zweifel BS, Seelbert K, Needeeman P. Selective regulation of cellular cyclooxygenase by dexamethasone and endotoxin in mice. J Clin Invest. 1990;86:1375-9.

14. O'Bannion MK, Win VD, Young DA. Temporal and pharmacologic division of fibroblast cyclooxygenase expression into transcriptional and translational phases. Natl Acad Sci USA 1992;89:4888-92.

15. Vane JR, Botting RM. Anti-inflammatory drugs and their mechanism of action. Inflamm Res. 1998;47(Suppl 12):578-87.

16. Whittle BJ, Higgs GA, Eakins KE, Moncada S, Vane JR. Selective inhibition of prostaglandin production in inflammatory exudates and gastric mucosa. Nature 1980;284:271-3.

17. Moncada S, Gryglewski R, Bunting S, Vane JR. An enzyme isolated from arteries transforms prostaglandin endoperoxides to an unstable substance that inhibits platelet aggregation. Nature. 1976;263:663-5.

18. Lyons-Giordano B, Prata MA, Galbraith W, Davis GL, Arner EC. Interleukin-I differentially modulates chondrocyte expression of cyclooxygenase-2 and phospholipase A2. Exp Cell Res. 1993;206:5862. 
19. Berenbaum F, Jacques C, Thomas G, Corvol MT, Bereziat G, Masliah J. Synergistic effect of interleukin-l beta and tumor necrosis factor alpha on PGE2 production by articular chondrocytes does not involve PLA2 stimulation. Exp Cell Res. 1996;222:379-84.

20. Okada Y, Lorenzo JA, Freeman AM, Tomita M, Morham SG, Raisz LG, et al. Prostaglandin G/h synthase-2 is required for maximum formation of osteoclast-like cells in culture. J Clin Invest. 2000;105:823-32.

21. Weinnreb M, Suponitzky I, Keila S. Systemic administration of an anabolic dose of PGE2 in young rats increases the osteogenic capacity of bone marrow. Bone. 1997;20:521-6.

22. Suponitzky I, Weinnreb M. Differential effects of systemic prostaglandin E2 on bone mass in rat long bones and calvarie. J Endocrinol. 1998;156:51-7.
23. Forwood MR. Inducible cyclooxygenase (COX-2) mediates the induction of bone formation by mechanical loading in vivo. J Bone Miner Res. 1996;11:1688-93.

24. Duncan RL, Turner CH. Mechanotransduction and the functional response of bone and mechanical strain. Calcif Tissue Int. 1995;57:34458.

25. Dekel S, Lenthall G, Francis MJ. Release of prostaglandin from bone and muscles after tibial fracture. An experimental study in rabbits. J Bone Joint Surg Br. 1981;63:185-9.

26. Zhang X, Schwars EM, Young DA, Puzas E, Rosier RN, O'Keefe RJ. Cyclooxygenase-2 regulates mesenchymal cell differentiation into the osteoblast lineage and is critically involved in bone repair. J Clin Invest. 2002;109:1405-15. 